\title{
PASSIVE IMMUNITY TO WHITE SPOT SYNDROME VIRUS (WSSV) IN PENAEUS MONODON TREATED WITH MONOCLONAL ANTIBODIES OF THE HETEROLOGOUSLY PRODUCED VP28 VIRAL ENVELOPE PROTEIN
}

Jyh-Yih Chen

Marine Research Station, Institute of Cellular and Organismic Biology, Academia Sinica, 23-10, Dahuen Rd., Jiaushi, Ilan 262, Taiwan

Kumarasamy Anbarasu

Marine Research Station, Institute of Cellular and Organismic Biology, Academia Sinica, 23-10, Dahuen Rd., Jiaushi, Ilan 262, Taiwan

Chin-Yu Chen

Han Te Biotechnology Co., 24 Fl., 29 Jungjeng E. Rd., Sec. 2, Danshuei, Taipei 251, Taiwan

Ying-Chuan Lee

Han Te Biotechnology Co., 24 Fl., 29 Jungjeng E. Rd., Sec. 2, Danshuei, Taipei 251, Taiwan

Fan-Hua Nan

Department of Aquaculture, National Taiwan Ocean University, Keelung 202, Taiwan.

See next page for additional authors

Follow this and additional works at: https://jmstt.ntou.edu.tw/journal

Part of the Aquaculture and Fisheries Commons

\section{Recommended Citation}

Chen, Jyh-Yih; Anbarasu, Kumarasamy; Chen, Chin-Yu; Lee, Ying-Chuan; Nan, Fan-Hua; and Kuo, Ching-Ming (2010) "PASSIVE IMMUNITY TO WHITE SPOT SYNDROME VIRUS (WSSV) IN PENAEUS MONODON TREATED WITH MONOCLONAL ANTIBODIES OF THE HETEROLOGOUSLY PRODUCED VP28 VIRAL ENVELOPE PROTEIN," Journal of Marine Science and Technology. Vol. 18: Iss. 1, Article 18.

DOI: 10.51400/2709-6998.1876

Available at: https://jmstt.ntou.edu.tw/journal/vol18/iss1/18

This Research Article is brought to you for free and open access by Journal of Marine Science and Technology. It has been accepted for inclusion in Journal of Marine Science and Technology by an authorized editor of Journal of Marine Science and Technology. 
PASSIVE IMMUNITY TO WHITE SPOT SYNDROME VIRUS (WSSV) IN PENAEUS MONODON TREATED WITH MONOCLONAL ANTIBODIES OF THE HETEROLOGOUSLY PRODUCED VP28 VIRAL ENVELOPE PROTEIN

Acknowledgements

This work was funded by a grant from the Marine Research Station, Institute of Cellular and Organismic Biology, Academia Sinica, Jiaushi, Ilan

Authors

Jyh-Yih Chen, Kumarasamy Anbarasu, Chin-Yu Chen, Ying-Chuan Lee, Fan-Hua Nan, and Ching-Ming Kuo 


\title{
PASSIVE IMMUNITY TO WHITE SPOT SYNDROME VIRUS (WSSV) IN PENAEUS MONODON TREATED WITH MONOCLONAL ANTIBODIES OF THE HETEROLOGOUSLY PRODUCED VP28 VIRAL ENVELOPE PROTEIN
}

\author{
Jyh-Yih Chen*, Kumarasamy Anbarasu*, Chin-Yu Chen**, Ying-Chuan Lee**, \\ Fan-Hua Nan***, and Ching-Ming Kuo*
}

Key words: white spot syndrome virus, Penaeus monodon, monoclonal antibody, immersion, oral administration.

\section{ABSTRACT}

White spot syndrome virus (WSSV) is a highly pathogenic and prevalent virus affecting shrimp culture worldwide including Taiwan. In the present study, the viral envelope protein, VP28, gene of the WSSV was cloned into a pET28a expression vector. VP28 was expressed as a protein with a 6-histidine tag in Escherichia coli and purified by a Ni-NTA column. Antiserum was raised against this recombinant VP28 protein in BALB/C mice, and it recognized the VP28 protein in purified virions and recombinant proteins. The antiserum was mixed with arginine (100 ppm), lysine (168 ppm), and phenylalanine $(88 \mathrm{ppm})$, and the titer of the antibody was $20,000-$ fold $/ \mathrm{ml}$. A series of monoclonal antibodies was tested for their ability to neutralize WSSV infectivity by immersion and oral administration. Our results proved that the antibody developed against the VP28 protein could efficiently prevent or control WSSV infection in post-larval and juvenile stages by immersion and oral administration. Furthermore, the postlarvae obtained from the antibody-treated group had $>60 \%$ survival after 20 days of challenge, illustrating that the antibody produced from heterologously expressed VP28 may specifically provide passive immunity against the WSSV pathogen. Therapeutic studies illustrated that shrimp losses could

Paper submitted 06/06/08; revised 03/19/09; accepted 04/08/09. Author for correspondence: Ching-Ming Kuo (e-mail: cmkuo@gate.sinica.edu.tw).

*Marine Research Station, Institute of Cellular and Organismic Biology, Academia Sinica, 23-10, Dahuen Rd., Jiaushi, Ilan 262, Taiwan.

**Han Te Biotechnology Co., 24 Fl., 29 Jungjeng E. Rd., Sec. 2, Danshuei, Taipei 251, Taiwan.

***Department of Aquaculture, National Taiwan Ocean University, Keelung 202, Taiwan. be controlled within 5 days of infection using this monoclonal antibody. These results should be considered in the light of the potential application of anti-VP28 antibodies as a prophylactic drug in aquaculture.

\section{INTRODUCTION}

Penaeus monodon has experienced many disease challenges in the aquaculture industry. One of the most significant of these is the white spot syndrome virus (WSSV) infection, and larvae and juveniles always carry the virus from their parents. Outbreaks of white spot disease (WSD) in cultured penaeid shrimp infected with the WSSV have caused mass mortality and serious economic losses worldwide. The mortality can reach $100 \%$ within $3 \sim 10 \mathrm{~d}$ after an infection in shrimp populations. In Taiwan, the first case report of epizootic disease was in 1992, followed by Japan in 1993, and China in 1995 [11, 3]. To the present, no solutions have completely controlled this viral disease.

To date, no effective prophylactic treatment measures are available for viral infections in shrimp and other crustaceans. A previous study reported that VP28 is a polypeptide with a predicted size of $22 \mathrm{kDa}$ and no significant similarity with other known proteins [2]. van Hulten et al. observed that incubation of the WSSV with rabbit polyclonal anti-VP28 serum lessened the mortality of live P. monodon [16]. Those above data and a report by Zhang et al. which suggested that VP28 is associated with the outer surface of intact WSSV virions indicate that VP28 can stimulate shrimp immunity to WSSV infection $[22,14]$.

Because the WSSV has such a wide host range and not only infects shrimp species but also many other crustaceans [9], developing new treatment methods is of the greatest urgency for aquaculture. Hence, developing a way of vaccinating shrimp against WSSV would be desirable. A previous publication on the copepod Macrocyclops albidus showed that a 
specific memory may exist in the defense system of this invertebrate species, which reacted more efficiently after encountering an antigenic parasite [7]. Extracted plasma from surviving shrimp after a WSSV infection can be used to neutralize WSSV from 20 to 60 days after infection [18]. These results suggest that an adaptive immune response may exist in shrimp, and protection against WSSV can possibly be induced in shrimp by a vaccination. Furthermore, a strategy was developed and adopted for protecting P. monodon against WSSV by oral vaccination [14]. Recently, a few studies have made efforts to develop polyclonal antibodies (pAbs) against specific viral peptides such as VP28 and VP19 and have obtained promising results with indoor experiments [17, 8]. Nevertheless, considering all these previous reports, in the present study, a monoclonal antibody (mAb) was developed against the VP28 peptide alone in high titers using hybridoma technology with a mouse model, and its prophylactic and treatment efficiencies were evaluated via immersion and oral routes in P. monodon, a highly susceptible species to WSSV.

\section{THE TRANSCEIVER STRUCTURE}

\section{Experimental Shrimp and Rearing Conditions}

In the present study, about 120,000 post-larvae (PL 15) were obtained from a shrimp hatchery in Pingtung, southern Taiwan, and transported to the Marine Research Station, Ilan, northern Taiwan by air and road transport in aerated bags. Upon arrival, they were randomly separated into eight 3000-L fiberglass tanks (200 m wide x $80 \mathrm{~m}$ high) each containing about 15,000 post-larvae, which were acclimatized and reared in ozone-treated seawater. In the rearing tank, the temperature $\left(26.4 \pm 1.4^{\circ} \mathrm{C}\right), \mathrm{pH}(8.06 \pm 0.26)$, and DO $(8.00 \pm 0.4 \mathrm{mg} / \mathrm{L})$ were recorded every day. Moreover, adequate continuous aeration and an open water system were maintained throughout the experiment. Sixty-day-old post-larvae from the control tank were considered juveniles $(1.25 \pm 0.27 \mathrm{~g}$ in weight and $4.12 \pm$ $0.31 \mathrm{~cm}$ in length) for determining the WSSV titration, and the challenge and therapeutic experiments. They were maintained in 50-L glass aquariums with open-water circulation and a continuous aeration system. They were fed ad libitum with commercially available prawn feed twice a day (at $8 \%$ of their body weight). The uneaten food and nitrogenous waste materials were siphoned out every day.

\section{WSSV Stock and Antigen}

The WSSV stock used in the present study was prepared from WSSV-infected tiger shrimp (P. monodon) which had predominant white spots on the exoskeleton and which were PCR-positive for the virus. The hepatopancreas and exoskeleton were collected and ground in $1 \mathrm{x}$ TN buffer $(20 \mathrm{mM}$ Tris-Base and $400 \mathrm{mM} \mathrm{NaCl}$; pH 7.4) at $0.25 \mathrm{mg} / \mathrm{ml}$ and centrifuged at $10,000 \mathrm{rpm}$ for $10 \mathrm{~min}$ at $4^{\circ} \mathrm{C}$; the supernatant was filtered $(0.45 \mu \mathrm{m})$ to remove impurities, followed by ultracentrifugation in a $\mathrm{CsCl}$ density gradient $(20 \%, 30 \%$, and
$40 \%$ ); then it was resuspended in $1 \mathrm{x}$ TN buffer and centrifuged again at $39,000 \mathrm{rpm}$ and $4^{\circ} \mathrm{C}$ for $18 \mathrm{~h}$. The solution was digested with proteinase $\mathrm{K}(100 \mu \mathrm{g} / \mathrm{ml})$ and a $1 / 10$ volume of lysis buffer (100 mM Tris- $\mathrm{HCl}$ (pH 8.0), $100 \mathrm{mM}$ EDTA, and $2.5 \% \mathrm{SDS}$ ) and incubated at $55^{\circ} \mathrm{C}$ for $24 \mathrm{~h}$. WSSV DNA was obtained by the phenol chloroform extraction method. Using the polymerase chain reaction (PCR), the VP28 envelope gene was amplified and sequenced.

\section{Cloning, Expression, and Purification of the Antigen}

The PCR-amplified VP28 fragment was eluted and purified after agarose gel electrophoresis. This DNA fragment (translated to a truncated VP28 protein) was cloned into the pET 28a vector, ligated, and transformed into Escherichia coli. The PCR primer design followed that of Witteveldt et al. [14]. The transformants were cultivated at $37^{\circ} \mathrm{C}$ for $3 \mathrm{~h}$, followed by the addition of $1 \mathrm{M}$ isopropyl- $\beta$-d-thiogalactopyranoside (IPTG) to a final concentration of $1 \mathrm{mM}$ to induce protein expression for another $3 \mathrm{~h}$ at $37^{\circ} \mathrm{C}$ with continuous shaking. The VP28 antigen protein was purified by His-tag metal affinity column chromatography with Ni-NTA agarose beads.

\section{Production of the $\mathrm{mAb}$}

The purified soluble antigen was used to produce the $\mathrm{mAb}$ in 6 8-week-old healthy BALB/C mice. The antigen $(100 \mu \mathrm{g})$ was emulsified with an equal volume of Freund's complete adjuvant (FCA) and injected intraperitoneally into the abdominal cavity. After 3 weeks, a booster dose was given at the same site and dose using Freund's incomplete adjuvant (FIA) prepared as described above. Three weeks later, a final injection was given with no adjuvant. Blood was drawn from a tail vein after 1 week, and the titers were determined by an enzyme-linked immunosorbent assay (ELISA). Before cell fusion, the BALB/C control mice were sacrificed, soaked in $75 \%$ ethanol, cleaned with iodine, and the abdominal cavity opened. Then $5 \mathrm{ml}$ of HAT select medium containing fetal bovine serum (FBS) was injected into the abdominal cavity. After $10 \mathrm{~min}$, the medium was aspirated, diluted with $5 \mathrm{ml}$ of fresh HAT medium, distributed into a 96-well ELISA plate, and incubated at $37^{\circ} \mathrm{C}$ with $5 \% \mathrm{CO}_{2}$; after fusion (days 3 and $4)$, the medium was changed.

In order to identify potential clones, all fusion-cloned hybridoma cells were screened by an ELISA. Purified antigen proteins (VP28) were diluted with $0.05 \mathrm{M}$ sodium carbonate buffer $(0.159 \%(\mathrm{w} / \mathrm{v})$ sodium carbonate and $0.293 \%(\mathrm{w} / \mathrm{v})$ sodium bicarbonate; $\mathrm{pH} 9.6$ ) to obtain $10 \mu \mathrm{g} / \mathrm{ml}$, and were added to each well in a 96-well ELISA plate. The plate was covered, incubated at $4^{\circ} \mathrm{C}$ overnight, and blocked with bovine serum albumin (BSA) at $37^{\circ} \mathrm{C}$ for $1 \mathrm{~h}$. The antigen solution was dumped out and washed with phosphate buffer $(\mathrm{pH} 7.4) 3$ times, each time for 3 5 min. One hundred microliters of the hybridoma cell suspension was added to each well, which was then filled with an equal volume of RPMI 1640, and cultivated at $37^{\circ} \mathrm{C}$ for $1 \sim 2 \mathrm{~h}$. The plate was again washed with phosphate buffer ( $\mathrm{pH} 7.4$ ) 3 times, each time for $3 \sim 5 \mathrm{~min}$, and 100 
$\mu 1 /$ well of the pre-diluted anti-mouse immunoglobulin $\mathrm{G}(\mathrm{IgG})$ enzyme-labeled secondary antibody was added, incubated at $37^{\circ} \mathrm{C}$ for $1 \sim 2 \mathrm{~h}$, and washed 3 times again. Finally, 100 $\mu 1 /$ well of the OPD-peroxidase substrate was added and incubated at room temperature for $30 \mathrm{~min}$ without light. After color development, $50 \mu \mathrm{l}$ of a stop solution (2 M sulfuric acid) was added to each well, and the solutions were examined in an ELISA reader at $490 \mathrm{~nm}$. Serum (diluted 100-fold) from immunized mice was used as the positive control, while serum from myeloma cells was used as the negative control.

Feeder layers were prepared from ascites fluid of healthy BALB/C mice. Positive hybridomas were diluted (1 clone/ $100 \mu \mathrm{l})$, distributed in 96-well microtiter plates, and incubated with $5 \% \mathrm{CO}_{2}$ at $37^{\circ} \mathrm{C}$. The medium was changed once every 3 days. The antibody titer was determined after 8 10 days; positive wells were labeled, and fresh medium was again added. The mAb was diluted in ratios of $1 \times 10^{-2}, 2 \times 10^{-2}, 1 \times$ $10^{-3}, 2 \times 10^{-3}$, and $1 \times 10^{-4}$ and analyzed by Western blotting to confirm the antibody specificity and titer. Briefly, the VP28 protein was transferred to nylon membranes from a sodium dodecylsulfate polymerase chain reaction (SDS-PAGE) in a semi-dry blotter (PantherTM Semidry Electroblotter) at 120 $\mathrm{mA}$ for $70 \mathrm{~min}$. The membrane was placed in blocking buffer (5\% non-fat milk powder in TBST (20 mM Tris- $\mathrm{HCl}, 150 \mathrm{mM}$ $\mathrm{NaCl}$, and $0.05 \%$ Tween-20) ) for $1 \mathrm{~h}$, washed with TBST buffer for $5 \mathrm{~min}$, and incubated with $5 \mathrm{ml}$ of blocking buffer containing primary antibody for $2 \mathrm{~h}$ at room temperature (RT). After hybridization, the membrane was again washed with TBST for $5 \mathrm{~min}$ and incubated with $5 \mathrm{ml}$ of blocking buffer containing the secondary antibody for $1 \mathrm{~h}$ at RT. The membrane was washed twice with TBST for 10 min and washed 3 times with TBS $(20 \mathrm{mM}$ Tris- $\mathrm{HCl}$ and $150 \mathrm{mM} \mathrm{NaCl})$ for 5 min. Finally, the membrane was developed with $10 \mathrm{ml}$ of APB staining solution containing nitro blue tetrazolium (NBT) and 5-bromo-4-chloro-3-indolyl-phosphate (BCIP) at room temperature.

\section{Immersion and Oral Administration Experiments}

In the present study, 4 different experimental trials were adopted to determine the prophylactic and therapeutic efficiencies of the mAb. The antiserum was mixed with arginine (100 ppm), lysine (168 ppm), and phenylalanine (88 ppm), and the titer of antibody was $20,000-$ fold $/ \mathrm{ml}$. A series of $\mathrm{mAbs}$ was tested for their ability to neutralize WSSV infectivity by immersion and oral administration. The other parameters remained the same throughout the experiment. The water temperature was maintained at $26.4 \pm 1.4^{\circ} \mathrm{C}$ during the entire experimental period.

\section{Experiment 1}

About 150 juveniles were transferred to a 50-L glass tank and divided into 5 groups in triplicate from the control tank in experiment 1 . They were exposed to different concentrations of WSSV (group 1, $200 \mu \mathrm{l}$; group 2, $300 \mu \mathrm{l}$; group 3, $400 \mu \mathrm{l}$; group 4, $500 \mu \mathrm{l}$; and group 5, the control; each group contained

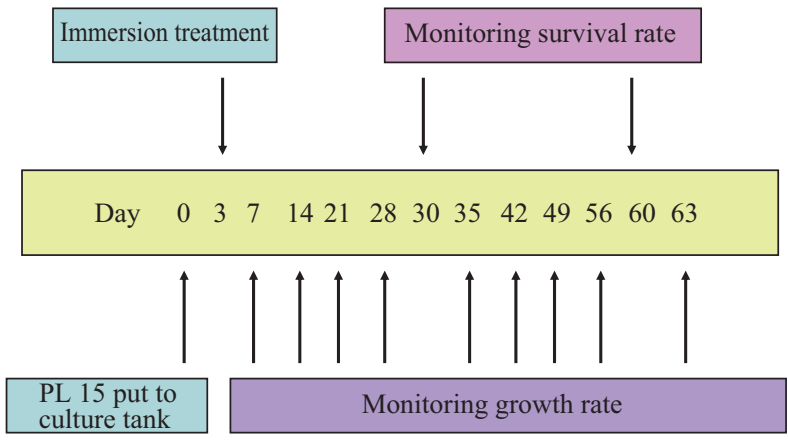

Fig. 1. Schematic diagram of the post-larval experimental design.

30 juveniles) through feeding twice a day to determine the juvenile challenge virus titer. It was prepared by adding appropriate amounts of the virus solution/TN buffer with $1 \mathrm{ml}$ of seawater, and fed to the shrimp $1 \mathrm{~h}$ after incubation. This condition was maintained until the end of the experiment. Shrimp mortality was continually monitored (4 times/day) and recorded.

\section{Experiment 2}

The mAb experiments scheduled in the post-larval stage are diagrammatically presented in Fig. 1. The acclimatized postlarvae ( 3 days after receiving the $\mathrm{mAb}$, each quantified with about 15,000 shrimp) were transferred to 4 individual tanks for $1 \mathrm{~h}$ of pretreatment with $75 \mathrm{~L}$ of seawater with $150 \mathrm{ml}$ of the antibody for the antibody group, $1.25 \mathrm{ml}$ virulent WSSV for the virus group, $150 \mathrm{ml}$ antibody $+1.25 \mathrm{ml} \mathrm{WSSV}$ for the antibody + virus group, and seawater alone for the control group. They were incubated for about an $1 \mathrm{~h}$ at $26^{\circ} \mathrm{C}$, and then returned to the 3000-L rearing tanks. They were fed commercially available powdered feed (P-1) for the first 30 days and $\mathrm{P}-2$ for the subsequent duration at about $8 \%$ of their body weight 4 times a day. On 2 occasions, $15 \mathrm{ml}$ of antibody was mixed with feed for the antibody and antibody + virus groups and incubated for $1 \mathrm{~h}$ before feeding to allow the antibody to adhere to the feed, while for the virus and control groups, the feed was only mixed with $15 \mathrm{ml}$ of seawater. The post-larval cumulative survival and growth rates were determined once at 30 and 60 days or every 7 days for up to 8 weeks, respectively, until the end of the experiment. This experiment was run in triplicate.

\section{Experiment 3}

Antibody-treated and control juvenile survival rates were estimated by obtaining juveniles weighing $>1 \mathrm{~g}$ fed the PL feed antibody with feed mixture every day and those from control tanks with feed but no antibody and divided them into 4 groups for treatment with the antibody (Ab), WSSV virus $(\mathrm{V})$, antibody + virus $(\mathrm{Ab}+\mathrm{V})$, or control $(\mathrm{C})$. Thirty juveniles were maintained in each tank with 3 triplicates. Five milliliters of antibody and $250 \mu \mathrm{l}$ of virus were mixed with feed twice a day. The tanks were kept at room temperature. In 
the control and virus groups, $5 \mathrm{ml}$ of seawater was added. Juvenile mortality was recorded 4 times a day.

\section{Experiment 4}

To determine the therapeutic effect of the mAb, 180 juveniles were taken from the control tank and divided into 6 groups with triplicates; thus, each tank contained 10 juveniles. Except for the positive control, all other juveniles were exposed to $300 \mu \mathrm{l}$ of the infective virus on day 0 . After $1,3,5$, and 7 days, different groups were treated with $5 \mathrm{ml}$ of antibody twice a day until the end of the experiment. The negative control group was not treated with antibody. The mortality was recorded 4 times a day.

\section{Statistical Analyses}

Statistical analysis was performed using the SAS 8.0 software (Statistical Analysis System) for Windows.

\section{RESULT}

\section{Expression of VP28 in the E. Coli Protein Expression System}

Viral DNA was amplified by a PCR and cloned into the pET28a vector. Five clones were chosen and identified by sequencing. One of the VP28 clones was transformed into the E. coli BL21 DE3 strain to induce IPTG. The expressed recombinant VP28 protein was visualized by Coomassie blue staining after SDS-PAGE and confirmed by reaction with the mAb (Fig. 2).

\section{Production and Characterization of mAbs}

Supernatant fluids from hybridoma cultures were screened by recombinant VP28 protein based on an ELISA at 2 weeks after fusion. Finally, 5 clones were shown to have high optical density (OD) values on an ELISA reader. The mAbs were identified by Western blotting using the purified virus and were confirmed to express the recombinant VP28 protein (Fig. 2).

\section{In vivo Test by Immersion and Oral Treatment}

In the study of juvenile susceptibility to various WSSV concentrations (Fig. 3), it was demonstrated that $100 \%$ mortality occurred in both groups of juveniles exposed to 400 and $500 \mu \mathrm{l}$ on day 10 and to 200 and $300 \mu \mathrm{l}$ on day 20 , which illustrates that $200 \sim 300 \mu \mathrm{l}$ of WSSV are concentrations to which P. monodon juveniles are susceptible. Figure 4(a) shows the post-larval survival 30 and 60 days after immersion and oral treatment with the mAb. The results clearly illustrate that the antibody-treated groups had much-higher survival rates than their untreated counterparts. The antibody- and virus-treated groups also showed elevated survival rates compared to the control and virus-treated groups until the end of the experiment, which directly illustrates the efficiency of the mAb against WSSV during the early stage of development. The

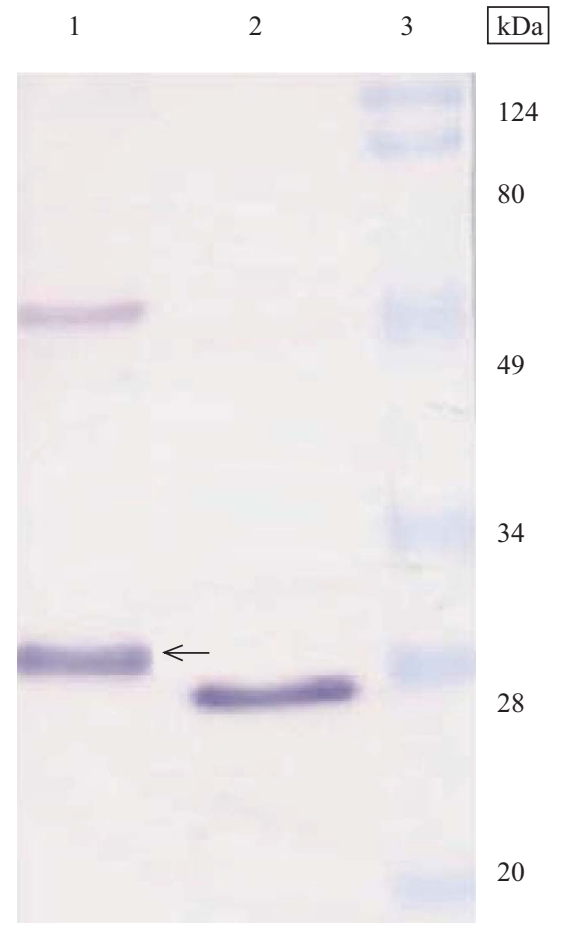

Fig. 2. Western blot of the virion of WSSV (lane 1, as indicated by the arrow) purified by $\mathrm{CsCl}$ gradient centrifugation and the recombinant VP28 protein (lane 2) of the anti-VP28 monoclonal antibody. Lane 3 is the protein marker. Numbers on the right side indicate the positions of the protein marker.

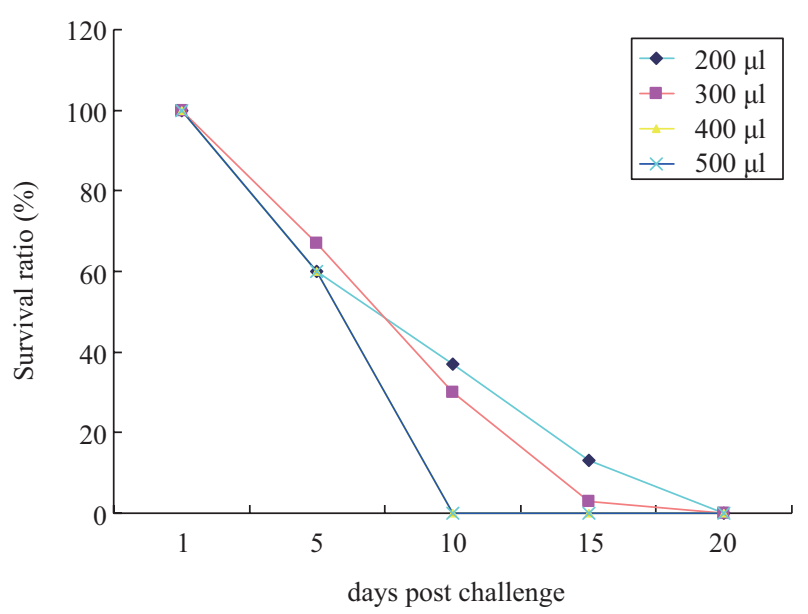

Fig. 3. Titration of WSSV in Penaeus monodon shrimp. Time postchallenge in days after incubation with different concentrations of WSSV for $60 \mathrm{~min}$ and various days are shown on the abscissa, and the survival ratio $(\%)$ is on the ordinate.

post-larval growth rate (as assessed by weight gain) was also directly proportional to the results of the survival study (Fig. 4(b)). The antibody-treated group had a significantly elevated growth rate compared to all other groups; on the other hand, the antibody + virus-treated groups did not have a significantly higher growth rate compared to the control, even though the 


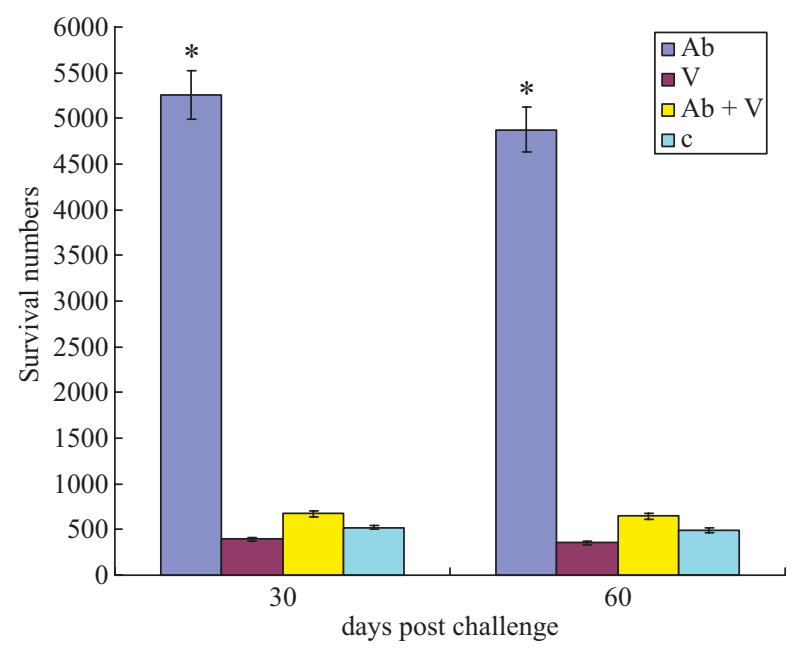

(a)

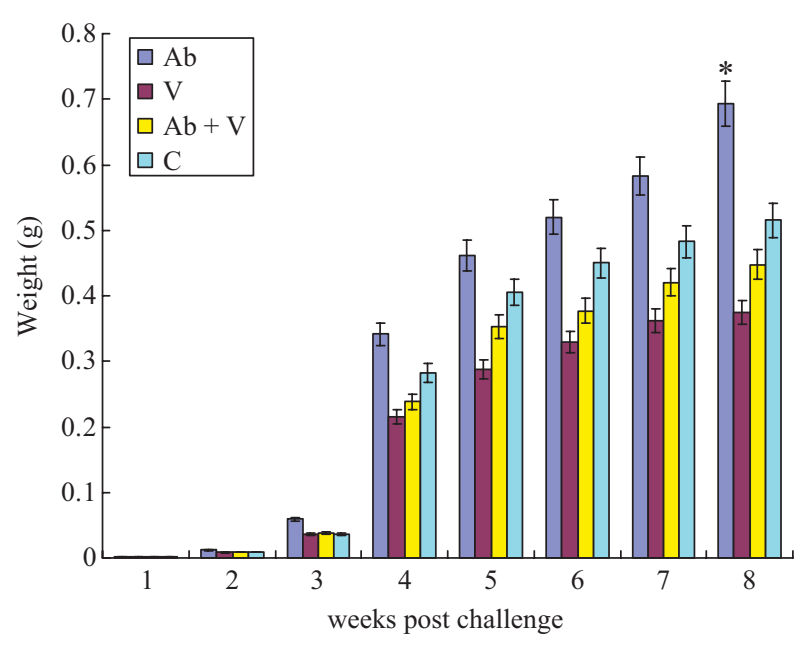

(b)

Fig. 4. (a) Time/surviving number relationship of immersion experiment 1. Mortality is expressed as the surviving number on various days post-challenge. Four groups were treated with the antibody (Ab), WSSV virus $(\mathrm{V})$, or antibody + virus $(\mathrm{Ab}+\mathrm{V})$, or untreated (control; C). Numbers of animals used in each experiment were 15,000 shrimp. (b) Time/growth rate relationship of immersion experiment 2 . The asterisk $(*)$ indicates a significant difference from the other treatment groups.

antibody placed together with WSSV may have neutralized the WSSV's infective ability. Nevertheless, it was slightly higher than that of the virus-treated group on almost all sample days. These results strongly illustrate that the antibody and healthy control post-larvae grew faster than virus-infected organisms. Furthermore, shrimp given the antibody treatment after virus infection did not recover the lost weight. These studies led us to propose 2 hypotheses: prevention is better than a cure as the non-infected control group and the group treated by antibody alone grew better than the infected group, and WSSV infection greatly reduced the growth rate of $\mathrm{P}$. monodon post-larvae.

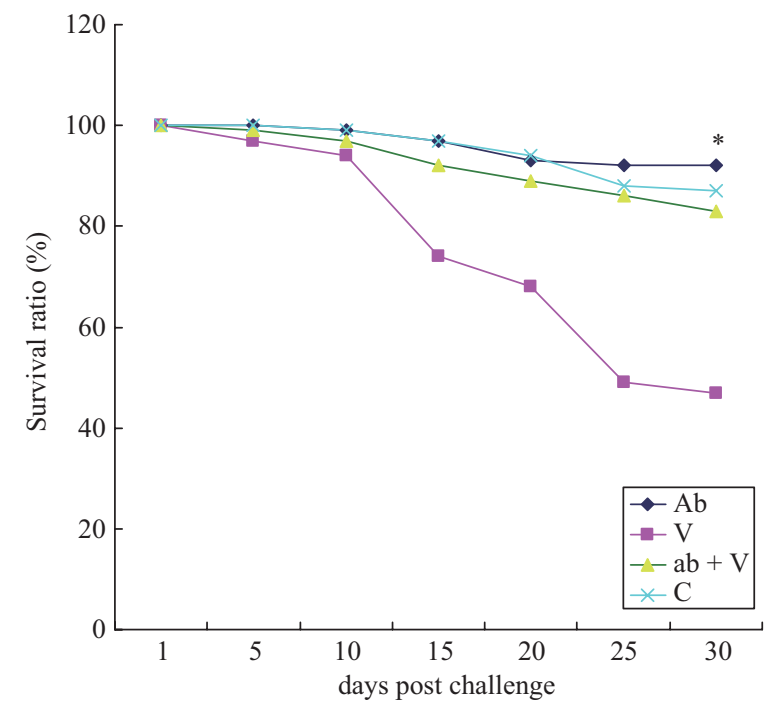

(a)

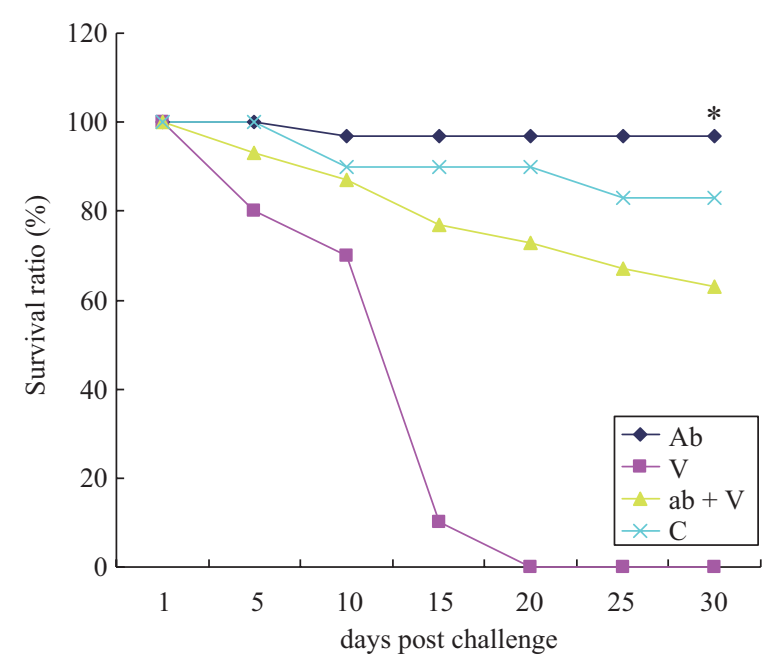

(b)

Fig. 5. (a) Treatment of post-larvae (PL 15) with antibody for $60 \mathrm{~min}$ at $26^{\circ} \mathrm{C}$ by immersion. After this, from the PL 15 stage to juveniles (weight $>1 \mathrm{~g}$ ), feed combined with the antibody mix was given every day. Thirty juvenile shrimp were divided into 4 groups treated with the antibody (Ab), WSSV virus (V), or antibody + virus $(A b+V)$, or untreated (control; C). The percentage survival rate was assessed for different treatment groups. An asterisk (*) indicates a significant difference from the other treatment groups. (b) Thirty juvenile shrimp were divided into 4 groups and treated with the antibody (Ab), WSSV virus (V), or antibody + virus $(A b+V)$, or untreated (control; C). These experimental shrimp were treated with no antibody or virus before the experiments. The percentage survival rate was assessed for the different groups during treatment. An asterisk (*) indicates a significant difference from the other treatment groups. (a and b) Relationship of the survival ratio with the time post-challenge in days for oral administration in experiment 3.

The results for juveniles (Fig. 5(a)) obtained from the antibody-treated post-larval studies clearly illustrate the efficiency of the mAb treatment against the WSSV pathogen. In 
different experimental groups, the survival exceeded $80 \%$ to the end of the experiment. Groups treated with antibody alone showed the highest survival followed by the control, then the antibody + virus-, and virus-treated groups. Interestingly, we noted a better percentage $(75 \%)$ of survival in the viruschallenged group up to day 20 , after which it rapidly decreased to $48 \%$ on days 25 and 30 . This result clearly demonstrates that with post-larval antibody exposure, juveniles can withstand WSSV infection for a very long time. However, juveniles obtained from the control rearing tank (Fig. 5(b)) showed no significantly higher survival rates during WSSV challenge. The results indicate that the antibody-treated groups had better survival compared to the untreated groups. The virus-challenged group showed $100 \%$ mortality within 10 days, which illustrates that juveniles are also susceptible to WSSV infection, while the antibody- and virus-treated groups had more than $60 \%$ survival to the end of the experiment. These findings illustrate that the mAb is effective when administered to juveniles via mixing it with feed. Results of the therapeutic effect of the antibody against WSSV (Fig. 6) clearly demonstrated that both the positive control group and the group treated with the antibody for 1 day showed better relative percent survival rates than did the other groups (97\% and $93 \%$, respectively). In the negative control group, $100 \%$ mortality was observed on day 21, and treated groups on days 3 and 5 after treatment showed more than $60 \%$ and $50 \%$ survival, respectively, to the end of the experiment (30 days), which clearly demonstrates that the mAb can be used as a passive vaccine within 5 days of onset of infection.

\section{DISCUSSION}

In the present study, a high-titer $\mathrm{mAb}$ was developed against the WSSV-VP 28 protein in mice by hybridoma technology, and its efficiency was determined in post-larvae and juveniles of the WSSV-susceptible tiger shrimp, P. monodon, by immersion and oral administration. These are the most practical and easiest immunization routes and can be adopted even by laymen in the field; in addition, these cause only a little stress to organisms. Even though it is generally believed that invertebrates do not have as well-developed adoptive defense mechanisms as vertebrates due to the lack of defined lymphoid organs [6], some scientific reports have, nevertheless, raised questions about such ideas. For example, it has been reported that some invertebrates such as P. monodon and P. japonicus have some level of a memory response against bacteria [1, 4]; that the copepod, Macrocyclops albidus, has a response against tapeworm parasites [7], Schistocephalus solidus; and P. monodon responds to viral pathogens [18]. Moreover, the pAbs recently developed against virus subunits (VP28 and VP19) were shown to possess the potential to protect P. monodon, P. chinensis, and crayfish (Cambarus clarkia) against WSSV infection $[5,8,14]$. Even though no commercial vaccines or mAbs are yet available to prevent or treat this contagious virus which has caused disease outbreaks

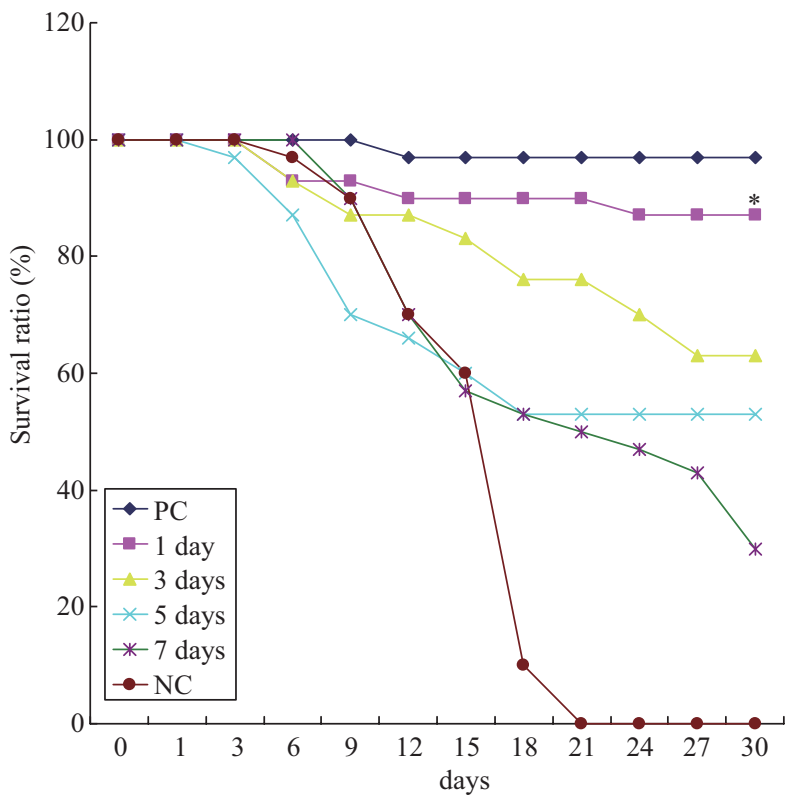

Fig. 6. Monoclonal antibody therapeutic efficiency after different lengths (days) of WSSV challenge. Treatment of the 6 groups used are described in experiment 4. An asterisk indicates a significant difference from the other treatment groups. NC, only treated with virus; PC, untreated, i.e., no virus or antibody.

worldwide [19], the developed pAbs against subunit peptides are widely used for identifying envelope proteins by neutralization assays, ELISA, Western blotting, and immunoelectron microscopic studies. However, researchers hope that with the help of the aforementioned pAbs, passive immunization against WSSV will be possible in shrimp [14]. The present study is in line with the above concept and is the first attempt to produce high titers of a mAb against a single WSSV peptide (VP28) and to determine its prophylactic and therapeutic efficiencies in tiger prawn (P. monodon) post-larvae and juveniles via a natural route.

In the present study, the efficiency of the mAb was measured in post-larvae (PL15) and juveniles, and in the near future, we plan to perform experiments using all stages and different routes. Infectivity studies in this context illustrate that all developmental stages of P. monodon, such as nauplii, protozoeae, zoea, mysis, early post-larvae (PL 1 10), late post-larvae (PL 10 20), and juveniles, are susceptible to infection; among these, the late post-larvae and juveniles are more-highly susceptible than are the other stages [21]. Based on the results of the present study, we will attempt to confirm that the mAb developed against the VP28 subunit is a viable choice of a method for controlling and treating WSSV infection. Postlarval survival was many-fold higher when compared to the control organisms, which indicates that the mAb is able to protect P. monodon post-larvae from WSSV infection by enhancing their defense mechanisms. Moreover, antibody-treated shrimp had better growth rates compared to the controls. This is evidence of consequences of the health status of the shrimp, 
and the antibody-plus-virus treatment indirectly indicates that WSSV infection causes a drop in weight gain. The possible explanation of survival of virus-treated shrimp may be the existence of maternal antibodies or some other kind of innate immune response in those individuals.

Accumulated neutralization experiments proved that VP28 is a spike peptide present on the WSSV envelope which plays a pivotal role in systemic infection $[15,20]$. The VP28 peptide was selected as the antigen from which to develop the $\mathrm{mAb}$ in this study, and it was also expressed in high numbers in E. coli with the pET 28a vector. Moreover, soluble protein expression was used as a source of antigen to produce the mAb, because soluble antigens normally provoke better antigenicity than do insoluble antigens [8]. Previous oral-treatment studies also revealed that a mixture of VP19 and VP28 antibodytreated groups had comparatively lower relative survival rates than did the group vaccinated with VP28 alone, and those results revealed that a low titer of VP28 in the mixture and a lack of protection when using VP19 alone clearly reveal that the VP28 peptide plays a vital role in WSSV infection rather than having a synergistic effect [14]. In the present study, juveniles obtained from antibody-treated post-larvae exposed to the virus had $50 \%$ survival after 30 days of continuous virus exposure; on the other hand, juveniles obtained from the control tank showed $100 \%$ mortality within 20 days, which illustrates that vaccinating shrimp with the mAb during the post-larval stage is highly effective during their late growth period and reveals that shrimp have a specific memory response against WSSV. The antibody + virus-treated juveniles from the antibody and control tanks showed greater than $80 \%$ and $50 \%$ survival rates, respectively. Cellular structural biology studies demonstrated that WSSV lesions are first observed in the stomach, gills, and cuticular epidermis of shrimp and subsequently spread throughout the body, so the routes of immunization via immersion and oral intake are better choices when compared to the injection mode.

Losses in antibody-treated groups may have been due to some other virus infections or cannibalism; we observed that compared to the virus-infected group, the healthy control and antibody-treated groups had higher levels of cannibalism (data not shown). Hence, we suggest that after 20 days in the rearing tank, separation of shrimp based on size is a suitable method for obtaining better yields. In general, mixed virus infection is more commonly seen in shrimp disease [10], hence we suggest that before introducing post-larvae to a rearing pond, it is essential to evaluate different commercially available virus diagnoses. Passive immunity against shrimp diseases has not been well characterized. Kim et al. reported that the increase in the pAb in chicken egg yolk against WSSV viral protein truncated against VP28 and VP19 was efficient in preventing WSSV infection in P. chinensis [5]. Our therapeutic trial proved that passive immunization within 5 days of infection is able to prevent further shrimp losses. If mass vaccinations are carried out using this $\mathrm{mAb}$, it may be possible to prevent or control further losses due to WSSV virus infection.
The administration of substances is claimed to be one of the major limitations for treating or preventing aquatic diseases, and it also is the key factor determining the success or failure of a substance. In general, 3 different routes of vaccination are employed for aquatic organisms especially fish and shrimp, including injection, immersion, and oral routes, each of which has certain advantages and drawbacks [12]. Accumulating evidence from reports on injection methods reveals that they are most effective, but they cause great stresses to organisms, are very difficult to handle, are labor intensive, require skilled persons, and are time consuming and costly; moreover, it is impossible to inject small shrimp like post-larvae, and after this stage, it is very difficult to capture each shrimp from a culture pond and immunize it. Immersion is the preferred route of administration for post-larvae, however it requires a large quantity of substances. Even though the oral route of administration is very easy, its success has been very limited, even though this is the natural route of entry of pathogens.

In conclusion, the present study confirms that Penaeus monodon has a specific memory against WSSV infection; the monoclonal antibody produced against the VP28 protein was efficient in inducing a defense mechanism against the WSSV pathogen in post-larvae and juveniles; and WSSV infection leads to reductions in shrimp growth during the early developmental stages.

\section{ACKNOWLEDGMENTS}

This work was funded by a grant from the Marine Research Station, Institute of Cellular and Organismic Biology, Academia Sinica, Jiaushi, Ilan.

\section{REFERENCES}

1. Adams, A., "Response of penaeid shrimp to exposure to Vibrio species," Fish and Shellfish Immunology, Vol. 1, pp. 59-70 (1991).

2. Chen, L. L., Leu, J. H., Huang, C. J., Chou, C. M., Chen, S. M., Wang, C. H., Lo, C. F., and Kou, G. H., "Identification of a nucleocapsid protein (VP35) gene of shrimp white spot syndrome virus and characterization of the motif important for targeting VP35 to the nuclei of transfected insect cells," Virology, Vol. 293, pp. 44-53 (2002).

3. Chou, H. Y., Huang, C. Y., Wang, C. H., Chiang, H. C., and Lo, C. F., "Pathogenicity of a baculovirus infection causing white spot syndrome in cultured penaeid shrimp in Taiwan," Diseases of Aquatic Organisms, Vol. 23 pp. 165-173 (1995)

4. Itami, T., Yan, Y., and Takahashi, Y., "Studies on vaccination against vibriosis in cultured prawn Penaeus japonicus: I. J.," Shimonoseki University, Vol. 40, pp. 83-87 (1992).

5. Kim, D. K., Jang, I. K., Seo, H. E., Shin, S. O., Yang, S. Y., and Kim, J. W., "Shrimp protected from WSSV disease by treatment with egg yolk antibodies (IgY) against a truncated fusion protein derived from WSSV," Aquaculture, Vol. 237, pp. 21-30 (2004).

6. Kimbrell, D. and Beutler, B., "The evolution and genetics of innate immunity," Nature Genetic Review, Vol. 2, pp. 256-267 (2001).

7. Kurtz, J. and Franz, K., "Evidence for memory in invertebrate immunity," Nature, Vol. 425, pp. 37-38 (2003).

8. Li, H. X., Meng, X. L., Xu, J. P., Lu, W., and Wang, J., "Protection of crayfish, Cambarus clarkii, from white spot syndrome virus by polyclonal antibodies against a viral envelope fusion protein," Journal of Fish Dis- 
ease, Vol. 28, pp. 285-291 (2005).

9. Lo, C. F., Ho, C. H., Peng, S. E., Chen, C. H., Hsu, H. E., Chiu, Y. L., Chang, C. F., Liu, K. F., Su, M. S., Wang, C. H., and Kou, G. H., "White spot syndrome associated virus (WSBV) detected in cultured and captured shrimp, crabs and other arthropods," Diseases of Aquatic Organisms, Vol. 27, pp. 215-225 (1996).

10. Manivannan, S., Otta, S. K., Karunasagar, I., and Karunasagar, I., "Multiple viral infection in Penaeus monodon shrimp postlarvae in an Indian hatchery," Diseases of Aquatic Organisms, Vol. 48, pp. 233-236 (2002).

11. Nakano, H., Umezaza, S., Momoyama, K., Hiraoka, M., Inouye, K., and Oseko, N., "Mass mortalities of cultured kuruma shrimp, 'Penaeus japonicus, in Japan in 1993: epizootiological survey and infection trials,", Fish Pathology, Vol. 29, pp. 135-139 (1994).

12. Palm, R. C. Jr., Landolt, M. L., and Busch, R. A., "Route of vaccine administration: effects on the specific humoral response in rainbow trout Oncorhynchus mykiss," Diseases of Aquatic Organisms, Vol. 33, pp. 157 166 (1998).

13. Robalino, J., Payne, C., Parnell, P., Shepard, E., Grimes, A. C., Metz, A., Prior, S., Witteveldt, J., Vlak, J. M., Gross, P. S., Warr, G., and Browdy, C. L., "Inactivation of white spot syndrome virus (WSSV) by normal rabbit serum: implications for the role of the envelope protein VP28 in WSSV infection of shrimp," Virus Research, Vol. 118, pp. 55-61 (2006).

14. Tsai, J. M., Wang, H. C., Leu, J. H., Wang Andrew, H. J., Zhuang, Y., Walker, Peter. J., Kou, G. H., and Lo, C. F., "Identification of the nucleocapsid, tegument, and envelope proteins of the shrimp white spot syndrome virus virion," Journal of Virology, Vol. 80, pp. 3021-3029 (2006).

15. Van Hulten, M. C. and Vlak, J. M., "Identification and phylogeny of a protein kinase gene of white spot syndrome virus," Virus Genes, Vol. 22, pp. 201-207 (2001).

16. Van Hulten, M. C., Witteveldt, J., Peters, S., Kloosterboer, N., Tarchini, R., Fiers, M., Sandbrink, H., Lankhorst, R. K., and Vlak, J. M., "The white spot syndrome virus DNA genome sequence," Virology, Vol. 286, pp. 7-22 (2001).

17. Witteveldt, J., Vlak, J. M., and van Hulten, M. C., "Protection of Penaeus monodon against white spot syndrome virus using a WSSV subunit vaccine," Fish and Shellfish Immunology, Vol. 16, pp. 571-579 (2004).

18. Wu, J. L., Nishioka, T., Mori, K., Nishizawa, T., and Muroga, K., "A time-course study on the resistance of Penaeus japonicus induced by artificial infection with white spot syndrome virus," Fish and Shellfish Immunology, Vol. 13, pp. 391-403 (2002).

19. Wu, W., Wang, L., and Zhang, X., "Identification of white spot syndrome virus (WSSV) envelope proteins involved in shrimp infection," Virology, Vol. 332, pp. 578-583 (2005)

20. Yi, G., Wang, Z., Qi, Y., Yao, L., Qian, J., and Hu, L., "Vp28 of shrimp white spot syndrome virus is involved in the attachment and penetration into shrimp cells," Journal of Biochemistry and Molecular Biology, Vol. 37, pp. 726-734 (2004).

21. Yoganandhan, K., Narayanan, R. B., and Sahul Hameed, A. S., "Larvae and early post-larvae of Penaeus monodon (Fabricius) experimentally infected with white spot syndrome virus (WSSV) show no significant mortality," Journal of Fish Disease, Vol. 26, pp. 385-391 (2003).

22. Zhang, X., Huang, C., Xu, X., and Hew, C. L., "Identification and localization of a prawn white spot syndrome virus gene that encodes an envelope protein," Journal of General Virology, Vol. 83, pp. 1069-1074 (2002). 